\title{
IRSEETCONF
}

\section{DESIGN OF HIGH EFFICIENCY 4 KW INDUCTION MOTOR}

\author{
Bekir Dursun ${ }^{*}, 1$, Yunus Uzun ${ }^{2}$ \\ ${ }^{1}$ Department of Electrical and Energy, Vocational School of Technical Sci., \\ Trakya University, Edirne, Turkey \\ ${ }^{2}$ Department of Electrical and Electronics Eng., Faculty of Engineering, \\ Aksaray University, Aksaray, Turkey
}

*Corresponding author

\begin{abstract}
Induction motors are the most widely used motors because they have simple structures, low cost, easy to maintenance and they can be connected directly to the grid. But, the efficiency of these motors is partially low. Therefore, the improvement of $1 \%$ in the motor efficiency will result in an annual energy saving of 20 billion $\mathrm{kWh}$. In this study, a $4 \mathrm{~kW}$ induction motor design with has IE3 energy efficiency is conducted using ANSYS RMxprt tool. In order to increase the efficiency, many changes such as the use of copper in the rotor, slot type and shape change have been realized. A motor efficiency of close to $90 \%$ is obtained. This is a very good value for an induction motor with a power rating of $4 \mathrm{~kW}$.
\end{abstract}

Keywords: induction motor, efficiency, motor design

\section{Introduction}

Electrical energy is one of the most important elements for people. More than half of the electricity energy is consumed in industry. Approximately $75 \%$ of the electrical energy consumed in this area is used by electric motors (Wilde\&Brunner, 2011). In this case, the production of high efficient electric motors is one of most important issues. Because, considering the cost of an electric motor have purchase cost only $5 \%$ of total, and the remaining $95 \%$ is usage costs (Hoffman et al., 2018).

The electric motor which is most widely used in the industry is the induction motor. In comparison to other motors, the induction motor has some important advantages such a slow cost, easy maintenance, high reliability, furthermore it can be run with grid directly. The unique disadvantage of induction motor is a low efficiency (Sprangers et al., 2013). The losses of induction motors can be grouped as stator copper losses, core losses, rotor copper losses, 


\section{IRSETCONF}

friction-wind losses and other losses. Although these losses are minimized by the studies, the overall efficiency of these engines may vary from $70-95 \%$ depending on the power. Electric machines such as motors, generators and transformers are designed for maximum efficiency at rated values. Energy efficient induction motors for same input will have higher efficiencies and power factors at high speeds. When the motor operates at lower voltage for long time, stator and rotor current will increase, and because of that copper losses will increase (Grewal\&Rajpurohit, 2016).

Efficiency classes in electric motors are determined by the International Electrotechnical Commission (IEC) in 2014 according to IEC / EN 60034-30-1. According to this standard, electric motors are divided into four classes. These standards are shown in Tab. 1.

Table 1: The efficiency classes for motors

\begin{tabular}{|c|l|}
\hline IE4 & Super-Premium \\
\hline IE3 & Premium \\
\hline IE2 & High efficiency \\
\hline IE1 & Standart efficiency \\
\hline
\end{tabular}

If the motor power is high, the efficiency will be increased. While the efficiency values of small power motors are in IE1 and IE2 classes, it can be reached to IE3 and IE4 efficiency levels in medium and large power motors. Fig. 1 shows the efficiency values of the motor classes depending on the motor power.

Figure 1: The efficiency classes of electric motors depend on the power 


\section{IRSETCONF}

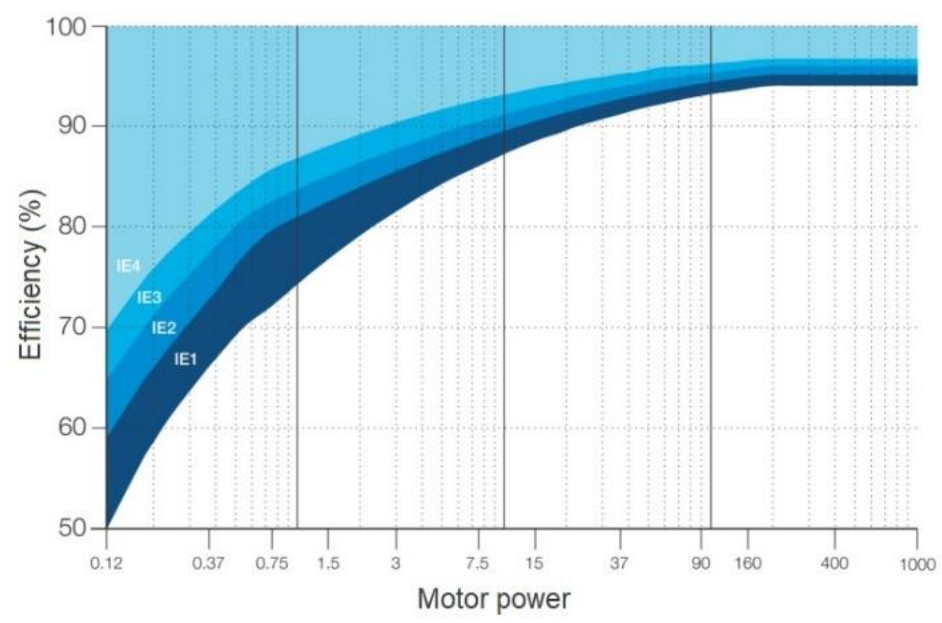

As it can be seen from the Fig.1, a motor has IE4 efficiency class if a $3 \mathrm{~kW}$ motor has $90 \%$ efficiency and a $100 \mathrm{~kW}$ motor has an efficiency rating of over $96 \%$. Induction motors are the most used motor type in the industry applications. A small efficiency increase leads to great energy savings (Grewal\&Rajpurohit, 2016). In this manner, an increase of $1 \%$ in the efficiency levels of induction motors will help an energy gain of 20 billion kWh per year. In addition, high efficient motors reduce greenhouse gas emissions with low energy consumption. Finite Elements Method (FEM) is widely used for induction motor design and analysis. Using the FEM, it is possible to realize very accurate analyses of electromagnetic systems (Bogliett et al., 2011), (Alberti\&Bianchi, 2008), (Gmyrek et al., 2010). In this study, an electric motor with a power rating of $4 \mathrm{~kW}, 112 \mathrm{M}$ frame and IE3 efficiency class was designed using ANSYS Maxwell RMxprt tool.

The electrical machinery designers use frequently ANSYS Maxwell and its RMxprt tool because it has easy user interface and truly results. After the design is realized, it can be transferred to 2D and 3D systems for more accurate results. Induction motors have stator copper losses, rotor losses, core losses, friction and windage losses, and stray losses. These losses can be decreased at some rate with small changes in motor design. Specially, it is possible to reduce core and rotor losses with appropriate designs.

\section{Simulations and Results}

There are two important stages of motor design, stator and rotor design, in general. But in detail, there are many parameters that affected motor design in point of efficiency, torque, harmonics etc. Some of them are number and shape of slots, core lamination selection, type and shape of windings, wire section and number. There is no any rule for determining the slot numbers for stator and rotor. But these values should have well determined considering weight, cost and characteristics of motor. For these power level the 36 slot stator 28 slot rotor structures 


\section{IRSETCONF}

are widely used. In this design these parameters were used. Squirrel cage induction motor use widely in industry. Squirrel construction consist of iron laminates core, and the aluminum or copper is filled to core slots. Copper was preferred for filling the rotor slots in this study, because of increase the efficiency. The selection of core laminates is very important for high efficiency. M19_24G type laminated steels were used for stator and rotor cores. Tab. 2 shows the design parameters of induction motor which has $4 \mathrm{~kW}$ power and 112M frame, and Fig. 2 shows view of stator and rotor structure in ANSYS RMxprt software.

Table 2: Design parameters of induction motor

\begin{tabular}{|l|l|l|l|}
\hline Output Power $(\mathrm{W})$ & 4 & Stator outer diameter $(\mathrm{mm})$ & 170 \\
\hline Rated Voltage $(\mathrm{V})$ & 380 & Stator inner diameter $(\mathrm{mm})$ & 105 \\
\hline Winding Connection & Delta & Rotor outer diameter $(\mathrm{mm})$ & 104.5 \\
\hline Number of Poles & 4 & Number of stator slot & 36 \\
\hline Frequency $(\mathrm{Hz})$ & 50 & Number of rotor slot & 28 \\
\hline
\end{tabular}

Figure 2: View of stator and rotor structure in the software

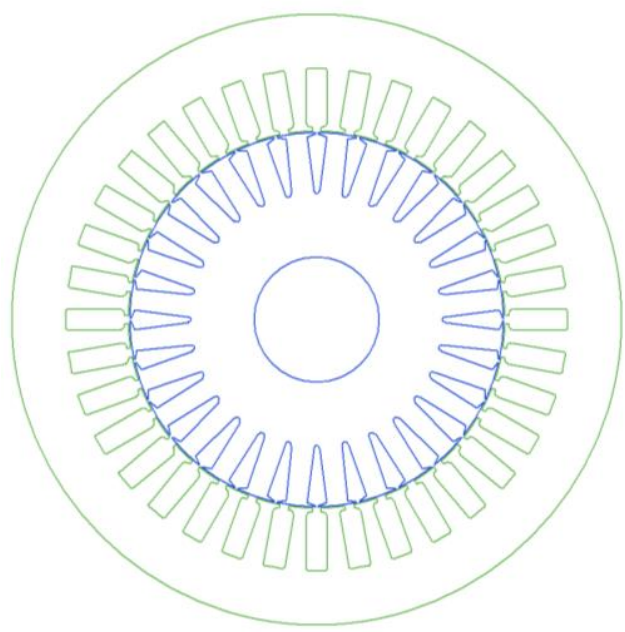

An important parameter affecting motor efficiency is the length of stator and rotor core. Stator and rotor core length is taken as $165 \mathrm{~mm}$. If it has more length, the motor efficiency is increased 


\section{IRSETCONF}

in only small scale, however motor will be bulky and expensive. Likewise, if motor length is shortened, the efficiency decreases rapidly. As a result of the simulations, for better efficiency value, stator slot is selected rectangular and rotor slot is oval. It is aimed to improve the starting torque of the motor thanks to the slot structure which gets thinner from outside to the center in the rotor. Concentric single layer winding was preferred for stator because it provide high efficiency and minimize balance problems.

In an induction motor, the current to be drawn depending on the power is at a certain value. In this case, it is very difficult to reduce the copper losses in the stator. The core losses can be reduced to a certain extent by selecting a quality core laminates. In this study, the core losses have been reduced using the core which have good quality. In addition to this, rotor losses are reduced by using copper bars and rings instead of aluminium in the rotor and also by providing high motor speed. Because rotor losses increase in direct proportional to slip. Tab. 3 shows output values of the induction motor.

Table 3: Result values of induction motor

\begin{tabular}{|l|c|l|c|}
\hline Copper Loss of Stator Winding & 254.53 & Output Power (kW) & 4000.4 \\
\hline Copper Loss of Rotor Winding & 60.13 & Mechanical Shaft Torque (N.m) & 25.85 \\
\hline Iron-Core Loss (W) & 89.04 & Efficiency (\%) & 89.99 \\
\hline Frictional and Windage Loss (W) & 41.28 & Power Factor & 0.787 \\
\hline Total Loss (W) & 444.97 & Rated Slip & 0.0146 \\
\hline Input Power (W) & 4445.37 & Rated Shaft Speed (rpm) & 1478 \\
\hline
\end{tabular}

Figure 3: The efficiency of motor depends on motor speed

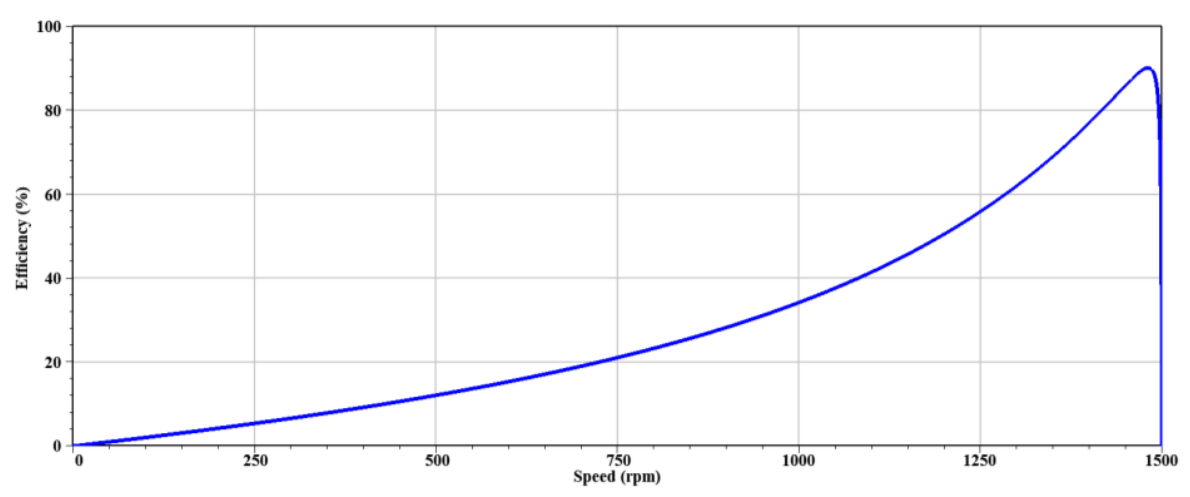

As it can be seen from the Fig. 3, the efficiency of the motor increases depending on the speed. The efficiency is measured as $89.99 \%$ at this time while the rated speed is $1478 \mathrm{rpm}$. The maximum efficiency is $90.03 \%$. Power factor is determined as 0.787 while working at nominal values. This motor is IE3 class in point of the efficiency. The air gap between the stator and the rotor is chosen 


\section{IRSETCONF}

as $0.25 \mathrm{~mm}$. Although this value is quite small, it is possible in today's technology. Thus, an improvement is achieved efficiency of $1.5 \%$ and starting torque of $50 \%$ when compared to $0.5 \mathrm{~mm}$ air gap. In addition, the power factor is improved.

Figure 4: The output torque versus motor speed

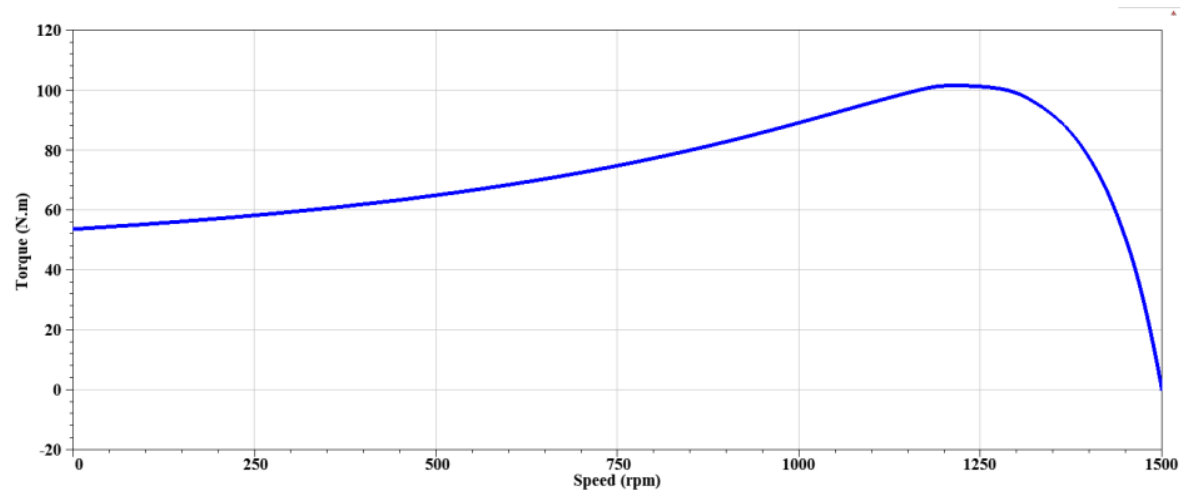

Fig. 4 shows the motor torque depend on motor speed. The starting torque of the motor is approximately $54 \mathrm{Nm}$. At the rated speed, the torque is determined as $25.85 \mathrm{Nm}$. This shows that the motor can be used not only for the fan type load, but also for loads that require high starting torque. The break-down torque of the motor is $101.37 \mathrm{Nm}$. This work is preliminary study for predicting induction motor parameters. The all of works which conducted by RMxprt can be transferred to 2D and 3D platforms of ANSYS. So, more realistic results can be obtained from these platforms.

\section{Conclusion}

An induction motor with $4 \mathrm{~kW}$ power design is realized with ANSYS RMxprt tool in this study. This tool provides important advantages for predicting motor parameters. In this work, some key changes have been made, such as the use of copper instead of aluminium in the rotor, keeping the air gap small, designing different stator and rotor slots. Furthermore, a quality core laminates is selected which have low iron losses. In this way, the efficiency of the motor is $90 \%$ and this value corresponds IE3 motor class. The most important improvement is obtained thanks to reduced core and rotor losses. 


\section{IRSETCONF}

\section{Refrences}

Wilde, C. and Brunner, U. (2011). "Energy-Efficiency Policy Opportunities for Electric MotorDriven Systems," International Energy Agency, Working paper.

Singha, G., Kumar, A. and Naikan, V.N.A. (2018). "Efficiency monitoring as a strategy for cost effective maintenance of induction motors for minimizing carbon emission and energy consumption," Reliability Engineering and System Safety, Vol.0, pp.1-9.

Sprangers, R.L.J., Paulides, J.J.H., Boynov, K.O., Waarma, J. and Lomonova, E.A. (2013). Design and optimization tools for high-efficiency three-phase induction motors, 15th European Conference on Power Electronics and Applications (EPE).

Grewal, G. S. and Rajpurohit, B. S. (2016). "Efficient energy management measures in steel industry for economic utilization," Energy Reports, Vol. 2, pp.267-273.

Bogliett, A., Cavagnino, A., Lazzari, M., Miotto, A. and Vaschetto, S. (2011). Induction motor design methodology based on rotor diameter progressive growth. 2011 IEEE Energy Conversion Congress and Exposition Date of Conference.

Alberti, L. and Bianchi, N. (2008). "A Coupled Thermal-Electromagnetic Analysis for a Rapid and Accurate Prediction of IM Performance", IEEE Trans. on Industrial Electronics, vol. 55, no. 10, pp. 3575-3582.

Gmyrek, Z., Boglietti, A. and Cavagnino A. (2010). "Estimation of Iron Losses in Induction Motors: Calculation Method, Results, and Analysis," IEEE Trans. on Industrial Electronics, vol. 57, no. 1, pp. 161-171. 